University of Montana

ScholarWorks at University of Montana

\title{
Underneath Kyoto: Emerging Subnational Government Initiatives and Incipient Issue-bundling Opportunities in China and the United States
}

Peter Koehn

University of Montana - Missoula, peter.koehn@umontana.edu

Follow this and additional works at: https://scholarworks.umt.edu/polisci_pubs

Part of the Political Science Commons

Let us know how access to this document benefits you.

\section{Recommended Citation}

Peter Koehn. (2008) Underneath Kyoto: Emerging Subnational Government Initiatives and Incipient Issuebundling Opportunities in China and the United States. Global Environmental Politics 8 53-77. MIT Press. DOI: $10.1162 /$ glep.2008.8.1.53

This Article is brought to you for free and open access by the Political Science at ScholarWorks at University of Montana. It has been accepted for inclusion in Political Science Faculty Publications by an authorized administrator of ScholarWorks at University of Montana. For more information, please contact scholarworks@mso.umt.edu. 


\section{Underneath Kyoto: Emerging Subnational Government Initiatives and Incipient Issue-Bundling Opportunities in China and the United States}

Peter H. Koehn

When we probe beneath the surface of climatic-change issues, we find that the people of China and the United States share much in common. The decisions and activities of both sets of policy makers and populations account for an inordinate share of the current and projected greenhouse-gas (GHG) emissions that threaten the quality of inhabitants' lives and those of all people's descendentsparticularly those who are least responsible for global warming. ${ }^{1}$ There is an urgent need for mitigating actions across the People's Republic of China (PRC) and the USA. Both national governments, however, continue to reject mandatory emission targets.

The primary subject of interest in this article is another, incipient and relatively unexplored, China-US convergence; that is, the emergence of emissionmitigating initiatives and prospects at the subnational government level. For instance, plans are underway for a new city of half a million people in Dongtan, an island in the Yangtze River across from Shanghai, that is intended to generate a zero contribution to global warming. ${ }^{2}$ In the United States, Salt Lake City, Utah, exceeded the emissions-reduction target of the Kyoto Protocol in its municipal-government operations "seven years early" (i.e., in 2005). "We believe that leadership begins at home, especially when it has been abdicated at higher

1. See Koehn 2007, 1085-1087; and Roberts and Parks 2006, 7-11, 37. Although the United States and the People's Republic of China both play major and growing roles in anthropogenic climatic change, differences in the extent of their respective responsibility are apparent when viewed in historical and per capita perspective. Specifically, China's emissions of carbon dioxide are of recent derivation and below average on a per capita basis, while US per capita GHG outputs have been and continue to be far above average. Gardiner 2004, 584; and Graham-Harrison and Wynn 2007. Roberts and Parks (2006, A8) calculate that, even today, "the average U.S. citizen dumps as much greenhouse gas into the atmosphere as nine Chinese citizens. . ."

2. Minneapolis Star Tribune, 15 May 2006. In the plan for Dongtan, "all manner of waste-sewage included-becomes fodder for biomass-derived electricity." 
levels of government," asserted Salt Lake City Mayor Rocky Anderson on behalf of some 250 US mayors committed to major GHG emission reductions. ${ }^{3}$

In the analysis of subnational policy initiatives and prospects in China and the United States, two concepts are particularly helpful. Multilevel governance allows us to situate the role of subnational governments within the dynamic multi-institutional decision-influencing context of global environmental politics. In addition, the diffuse and often imperceptible nature of climatic change necessitates an approach to emission-reduction efforts and prospects through a public-interest framing lens. Framing through local issue bundling, or tying together the co-benefits of previously distinct public concerns, enables municipal, state, and provincial government leaders to develop innovative and effective mitigation policies. ${ }^{4}$ The concluding comparison assesses subnational policy developments along with framing opportunities in the Peoples' Republic of China and the United States of America.

\section{Global Climatic Change: US and Mainland Contributions}

The USA and the PRC are the first and second largest annual contributors of $\mathrm{CO}_{2}$ emissions from fossil-fuel combustion. Although the United States only supports 5 percent of the world's population, its high per capita emission rate results in the generation of roughly 25 percent of total annual anthropogenic greenhouse gases. At their current rate of increase, moreover, US GHG emissions will be approximately 25 percent higher in 2012 than they were in 1990 .

China's contributions to global warming are rooted in industrial production, population dynamics, and "offshoring" of raw-materials exploitation. In recent years, Mainland industrial production has frequently increased by nearly 20 percent per annum. ${ }^{5}$ Reflecting on China's export-driven economy, a member of the Green River Chinese environmental NGO lamented that "highconsumption, high-pollution industries declining in other parts of the world flock here to churn out vast quantities of junk products . . ${ }^{\prime \prime}$ destined for Northern consumers. China's population now exceeds 1,300,000,000 people. Rising incomes and pent-up consumer demand render China's enormous population explosive in terms of GHG emissions. China's GHG-emissions take-off is generated, in part, by an unparalleled nation-wide construction boom of housing, office space, and roads. To satisfy its construction needs, the Mainland now produces more steel than Japan and the USA combined and "cement consumption is over 640 million tons per annum, a level six times higher than U.S. consumption."7

3. Anderson 2006, A8. By May 2007, the US Mayors Climate Protection Agreement had 500 signers. Kugler 2007, A7.

4. See Steinberg 2001, 203.

5. Hale 2004, 137.

6. Tan 2006, 34.

7. Hale 2004, 139. 
The combination of rapid urbanization, unleashed consumer demands, and robust manufacturing of exported products has catapulted China into the world's top position as an importer of industrial raw materials. ${ }^{8}$ The interaction of population and household growth, dramatic increases in per capita income and consumption, and continued expansion in domestic manufacturing accounts for the PRC's USA-surpassing trajectory as the world's top gross GHG emitter. ${ }^{9}$ As China turns overseas to quench its voracious thirst for nonrenewable resources, additional Mainland-associated GHG emissions are being generated by intensive offshore extraction and long-distance transportation processes.

\section{Kyoto and Beyond: Multilevel Governance ${ }^{10}$}

Climatic-stabilization efforts are enhanced when multiple actors and institutions at all levels of governance pursue complementary GHG-mitigation activities. Looking ahead to the post-2012 climate regime, supranational and multinational institutions, nation-states, subnational authorities, NGOs, transnational social movements, and citizen advocates all are important players in the politics of consumption, emissions reduction/limitation, and adaptation.

\section{National Government Roles and Framing in China and the USA}

In spite of the growing body of convincing evidence that atmospheric warming poses a serious threat to ecological sustainability and the well-being of their citizens, the national governments of China and the United States have steadfastly resisted pressures to adopt mandatory measures that would bring their worldleading GHG emissions under control. Based on comparative per capita emission and consumption figures, one can conclude that the US Government refuses to address reduction obligations while the Government of the PRC disregards limitation obligations.

As a non-Annex I (developing) country, China is not obliged under the Kyoto Protocol to adopt mandatory GHG-emission targets and the central government has shown no inclination to undertake concrete binding emissions commitments. The position on climatic-change policy articulated by PRC officials involves a mix of perceived national self-interest and commitment to the worldview shared by many countries in the global South. Party leaders continue to frame national stability as dependent upon industrial expansion and growth in GDP, lately coupled with high-level support for mitigating gross dis-

8. Hale 2004.

9. Several analysts have estimated that China's $\mathrm{CO}_{2}$ emissions surpassed US totals in 2007. Graham-Harrison and Wynn 2007.

10. For a discussion of the concept of multilevel governance as it is used here, see Bulkeley and Betsill 2003, 27-29. 
parities in wealth. ${ }^{11}$ In addition, the central government opposes setting concrete emission targets in the absence of prior commitment on the part of countries historically responsible for current levels of greenhouse gases (most notably, the United States) to curtail conspicuous consumption. ${ }^{12}$ By advocating the principles of historical responsibility, compensatory justice, and equal per capita atmospheric carbon-absorption entitlements, and by insisting that promoting economic development and global equity be included when negotiating international agreements that affect climatic stabilization, ${ }^{13}$ Mainland leaders are able to justify continued pursuit of their chosen growth-dependent path without incurring pressures for immediate emission-mitigation actions from poor countries that value China's leadership in advancing the South's agenda. ${ }^{14}$

While a growing number of China's political leaders have publicly recognized environmental protection, green development, and restrained resource consumption as additional core national policies, this discourse has had a negligible effect on the Mainland's emission trajectory. ${ }^{15}$ The central government has issued multiple laws and regulations dealing with air pollution and control, energy savings, and solid-waste prevention. ${ }^{16}$ Recently, the national leadership of the PRC emphasized clean-technology measures in the $11^{\text {th }}$ Five-Year Plan, introduced a renewable-energy target of 10 percent by 2020, and promised to treat reductions in energy usage and pollutants as "red lines that can't be crossed." 17 However, the national government's capacity to influence emission practices has diminished "as polluting state-owned enterprises are privatized and the political-economic decisions of China's central leadership lose their command-andcontrol certainty." 18 While "the state continues to devolve authority over environmental issues away from the center, delegating enforcement of both central and local government laws and regulations to local officials," ${ }^{19}$ central govern-

11. Bradsher 2006, C1; and Economy 2004, 185.

12. PRC, Central People's Government, 2007. Roberts and Parks note (2006, 225, 140-141) that "lack of progress (and backsliding) by the United States in meeting its own target for carbon dioxide emissions by the end of the decade has provided developing nations with a ready excuse for not making reductions."

13. Roberts and Parks 2006, 23, 26, 38, 45, 139, 144-145, 180, 184, 231; and Ma Kai 2007.

14. See Koehn 2004, 382-383.

15. With the exception of state policy regarding carbon sequestration. In 2006, China's State Forestry Administration agreed to follow the Climate, Community, \& Biodiversity Alliance's "CCB Standards" in the design of new forestry projects in Yunnan and Sichuan provinces. See www.climate-standards.org. To satisfy the country's voracious appetite for wood, however, China has offshored deforestation to Brazil, parts of Africa, and Indonesia. Friedman 2005b; and Perlez 2006.

16. See "Environmental Legislation" at www.chinacp.com/eng/cppub/print/cnenvleg.html; and PRC, State Council 2006.

17. The quotation is attributed to Zhou Shengxian, head of the State Environmental Protection Administration (SEPA). China Environment News 2006. Also see Friedman 2006; and Niederberger, Brunner, and Dadi 2006, 85.

18. Willmott 2006, 16 .

19. Economy 2005, 103, 106. 
ment incentives and political cover remain important for local government officials who are inclined to be innovative with regard to emission mitigation.

The George W. Bush Administration has consistently rejected the Kyoto Protocol to the United Nations Framework Convention on Climate Change. In late 2006, the Bush Administration continued to insist that it had no plans to accept binding emissions reductions. ${ }^{20}$ Instead of the emissions-reduction targets favored by a bipartisan majority of US citizens, ${ }^{21}$ the Bush Administration has called for voluntary efficiency enhancements, ${ }^{22}$ technology fixes, ${ }^{23}$ carbon sequestration, ${ }^{24}$ methane capture, ${ }^{25}$ stricter fuel-efficiency standards, and increased production of ethanol-blended fuels. ${ }^{26}$ In framing executive-branch opposition to the mandatory compliance targets of the Kyoto Protocol, President Bush contended that "for America, complying with those [Kyoto] mandates would have a negative economic impact." 27

Until recently, the US Congress also has been solidly against embracing the Kyoto Protocol. ${ }^{28}$ In the wake of the Democratic Party's capture of a majority of seats in the Senate following the November 2006 elections, Senator Barbara Boxer, the new chair of the Environment and Public Works Committee, indicated that she would place priority on legislation aimed at cutting GHG emissions. As long as President Bush's economy-damaging framing prevails in Washington, D.C., however, the outlook for US national government acceptance of mandatory GHG-emissions reductions and new targets that would commence in 2012 is not bright. ${ }^{29}$

\section{Subnational Initiatives}

In the face of the deep-rooted resistance to fundamental modifications in the expansionist economic policy that prevails in Beijing and Washington, climaticstabilization advocates who seek to reorient emissions-impacting decisions and

20. Gettleman 2006.

21. Specifically, a large majority favors US participation in the Kyoto Protocol (Kull 2005, 3-5) and higher automotive fuel-efficiency standards even if the latter increase the price of a car (University of Maryland Program on International Policy Attitudes 2004 polls cited in PA Times, February 2005, 2). National findings based on a New York Times/CBS News 2007 poll indicate that large bipartisan majorities favor immediate steps to reduce the effects of global warming (Broder and Connelly 2007).

22. Roberts and Parks 2006, 138-139, 144; and Rabe 2004, 14-15.

23. Newell 2000, 50-51; and Barringer 2006b, A27.

24. Nadler 2004, 16.

25. Janofsky 2004, A5.

26. Andrews and Barringer 2007.

27. Bush 2001, 546-547; and Roberts and Parks 2006, 142. This claim is undermined by estimates that, at the end of 2006, the actual costs of the war in Iraq alone will exceed high-end estimates of costs to the United States of full compliance with the Kyoto Protocol over many decades. See Sunstein 2006.

28. See Roberts and Parks 2006, 3, 140.

29. Glenn 2006, A17. 
population behaviors must rely on efforts that do not require national government leadership. Lack of national leadership shifts the focus of attention from failed attempts to reach international agreements to bottom-up change initiatives. This article identifies subnational policy and framing initiatives that possess potential for reducing greenhouse-gas emissions when national governments are unwilling to enter into and enforce binding international agreements. Subnational efforts also could be built into any future agreements on climatic stabilization should political change occur at the national level in the PRC and/ or the USA.

The domestic and transnational initiatives undertaken by nonstate actors constitute one promising alternative to national government inaction. ${ }^{30}$ In its first official act, for instance, the Clinton Foundation partnered with 22 of the world's most populous cities, including New York, Los Angeles, and Chicago, on projects aimed at reducing GHG emissions. ${ }^{31}$ More than 200 US university presidents have signed a "Climate Commitment" modeled on the US mayors' agreement that involves emission-reduction plans and curriculum innovations. ${ }^{32}$ Among other US NGOs that have identified climatic stabilization as a priority issue are the National Religious Partnership for the Environment and the recently formed Evangelical Climate Initiative. ${ }^{33}$ Transnationally networked epistemic communities are leading nonstate actors in climatic-change politics, although climatologists have been "resolutely unable" to change the policy position of the US national government toward the Kyoto Protocol. ${ }^{34}$

The focus of attention in this article is on subnational government institutions. Stalemate at the national level "produces the possibility for new forms of power and politics at the subnational level." ${ }^{\prime 35}$ In a number of policy and administrative-reform realms, local governments in both the PRC and the USA have been at the forefront of innovation and experimentation. ${ }^{36}$ Will subnational governments lead the way in limiting and mitigating post-2012 GHG emissions in China and the United States? Although underappreciated in scholarly circles, ${ }^{37}$ local political champions and municipal and state/provincial governments have been active in developing and sustaining creative framings that function to control GHG emissions "underneath" the nation-state orientation of the official Kyoto Protocol. ${ }^{38}$

30. For a detailed analysis of the emission-mitigating role of nonstate actors in China and the United States, see Koehn 2006.

31. Steinhauer 2006, A16.

32. Cohen 2007; and Vance 2007, A25.

33. Woodard 2006, 22. For an inventory of environmental NGOs active in China, see Turner (2002). On the spread of local NGOs generally in China, see Yu, et al. 2005, 92.

34. Newell 2000, 60-61.

35. Sassen 2004, 203.

36. See, for instance, Foster 2005, 10.

37. Vasi $(2005,67)$ notes that "very few scholars have analyzed local actions against global climate change ..." The principal exceptions are Betsill and Bulkeley and, with regard to US state government actions, the work of Rabe.

38. Bulkeley and Betsill $(2003,27)$ point out that the Framework Convention on Climate Change 


\section{Emerging Subnational Policy Initiatives}

Subnational governments offer particularly promising venues for GHGemissions mitigation. Annual GHG emissions in the state of Texas exceed those generated separately by the United Kingdom, France, Canada, and Italy. ${ }^{39}$ Recognition that cities cover less than 1 percent of Earth's surface, but generate 80 percent of total anthropogenic GHG emissions, underlies London Mayor Ken Livingstone's warning that "it is in cities that the battle to tackle climate change will be won or lost." 40 Subnational government officials possess authority to shape key processes and implementation measures affecting emissions (including energy standards for buildings, modes of transportation, tailpipe emissions, electricity generation, renewable-energy purchases, and recycling). ${ }^{41}$ They also have experience in addressing local environmental-protection issues and the capacity to mobilize powerful stakeholders. It is noteworthy, therefore, that the worldwide Cities for Climate Protection program established by one of the largest transnational networks of subnational government bodies, the International Council for Local Environmental Initiatives (ICLEI), had nearly 600 members (including 83 US cities) in 2002, "representing over 8 percent of total global greenhouse gas emissions." ${ }^{\prime 2}$ Each member has agreed to set a GHG-emissionsreduction target, formulate an action plan that will meet its goal, and implement and evaluate policies designed to attain the desired results. ${ }^{43}$

\section{China}

As a result of decentralization trends, fueled primarily by the shift from central planning to subnational economic decision making and by an explosion of domestic and transnational ties and partnerships with external actors, China's provinces, municipalities, and autonomous zones have acquired their own spheres of authority and independent means to exercise power. ${ }^{44}$ For more than a decade, local governments have possessed primary responsibility for the enforcement of environmental-protection regulations. A wide range of environmental-policy measures, including authority to levy taxes on coal burning, to subsidize cleaner energy sources, and to issue local regulations that supplement national laws and administrative regulations, are at their disposal..$^{45}$ One key

fails to mention "the role of local government or even of local action." In contrast, the Rio Declaration on Environment and Development emphasizes broad participation at the lowest policy levels. Rabe 2004, 16.

39. Rabe 2004, 4-5.

40. Kugler 2007.

41. Bulkeley and Betsill 2003, 2, 4, 49; and Rabe 2004, 4, 17.

42. Betsill and Bulkeley 2004, 477; and Vasi 2005, 67.

43. Betsill and Bulkeley 2004, 478; and Vasi 2005, 7-8. By 2000, 23 US local governments had developed local action plans. Bulkeley and Betsill 2003, 52.

44. See Orban, Chan, and Koehn 2003; Porter, Han, and Shidong 2003, 6; and Yu, et al. 2005, 33.

45. See, for instance, Porter, Han, and Shidong 2003, 21; and Ferris and Zhang 2005, 74-75. 
unit of governance at the subnational level is the environmental protection bureau. Officials employed by local environmental protection bureaus hold primary responsibility for environmental-impact assessments, monitoring factory emissions, assessing "polluter-pays" fees, and initiating legal action against entities that fail to comply with pollution standards. ${ }^{46}$

As a result of shifts in functional responsibility from the central to local levels, the direct impact of municipal government policies on the lives of urban residents has increased. This development enables subnational authorities to assume a vital framing role regarding environmental issues. Local environmental-protection bureaus "maintain critical links with the general populace through Web sites, hotlines, and educational programs" 47 that enhance their framing power. Until recently, however, the issue-bundling potential of China's newly empowered local governments has been largely ignored by multilateral organizations. ${ }^{48}$

The decentralized nature of China's administrative system encourages variability in subnational environmental-protection efforts. One observer suggests that "when the mayor is environmentally proactive, income levels are high, and the city is tightly integrated into the international community, local environmental protection has evidenced substantial progress over the past decade." ${ }^{49}$ Increasingly, the INGO community has been supporting local government environmental initiatives in the Mainland. One example is the concerted effort to help the Beijing Municipal Government realize the goal of "blue skies" over Beijing in time for the 2008 Olympics. ${ }^{50}$ Over the past decade, the Natural Resources Defense Council (NRDC) has helped Chengdu and Chongqing city governments develop clean building codes and the Energy Foundation has supported a number of energy-efficiency projects. ${ }^{51}$ In addition, the United Nations Development Programme's Capacity Development for China Green Lights project has trained local-level officials in ways to plan and implement incentive schemes that promote energy-efficient lighting. Other UNDP projects developed a widely disseminated city and provincial "health-risk index" and trained municipal officials on how to subsidize research and development of cleanenergy technology. ${ }^{52}$

Some of China's local governments have not strictly enforced environmental regulations because they view such actions as antithetical to the goal of economic development and because of financial ties to offending local enterprises. Moreover, local economic growth figures prominently in the perfor-

46. Economy 2005, 103; also see 107-108, 117.

47. Economy 2005, 103.

48. Chen and Uitto 2003.

49. Economy 2004, 117-119, 128, 260; and Economy 2005, 110-111, 117. Nearly a decade ago, Xiaoyuan Chen $(1998,11)$ noted that environmental-protection linkages were beginning to emerge among Mainland and US municipalities.

50. See China Environmental Forum 2002, 178-179; and Chiu, Green, and Sibold 2003, 46.

51. Zusman and Turner 2005, 137-138; and www.efchina.org.

52. Porter, Han, and Shidong 2003, 21, 23-24, 40. 
mance evaluations of China's appointed mayors. ${ }^{53}$ Many of the Mainland's township, county, city, and provincial government bodies also depend for financial resources (including pollution fines) on enterprises that disregard environmental regulations. ${ }^{54}$ In most places, therefore, the prevailing politicaladministrative context requires issue bundling in order for effective GHGlimitation efforts to be implemented at the subnational level.

\section{United States}

Scholars and the media have emphasized the US national government's failure to adopt international agreements and stringent forward-looking national policy and legislation in the face of climatic destabilization. While domestic and international critics have focused on national government inaction, direct and indirect state and local governments efforts to mitigate GHG emissions have intensified and expanded. By 2007, more than 20 states had adopted legislation or issued executive orders "expressly intended to reduce greenhouse gases." 55 California (a state that produced roughly two percent of the world's annual GHG emissions) and New Jersey have been in the forefront of these initiatives. In June 2005, California Governor Arnold Schwarzenegger issued an executive order calling for the state to reduce its GHG emissions to 1990 levels by $2020 .{ }^{56}$ Denver stands out as a city government that has explicitly integrated emissionsmitigation considerations into its core policies and organizational structure..$^{57}$ In 2006, voters in Boulder, Colorado, approved a carbon tax based on kilowatt hours that will generate revenue for a climate-action plan aimed at reducing the city's carbon emissions by 24 percent from current levels. ${ }^{58}$

Such subnational policy prescriptions serve to promote public awareness that climatic change is a serious problem and that unsustainable organizational and personal consumption exacerbates the problem. However, durable state/ local policy and population behavioral changes that limit or reduce GHG emissions remain the exception rather than the rule in the United States (and China) because the benefits of global climatic stabilization are not immediately discerned or appreciated by most consumers and policy makers. ${ }^{59}$ In some policymaking situations, visible emphasis on GHG-emission reductions alone would be counterproductive. For instance, one of the strongest supporters of the Texas effort to require utilities to provide renewable-power sources as part of their to-

53. Murray and Cook 2004, 143. In 2006, however, 30 mayors and provincial-level officials agreed to implement accountability systems that link career advancement to progress in improved energy efficiency. China Daily, 27 July 2006.

54. Porter, Han, and Shidong 2003, 17-18.

55. Rabe 2002, 7; and Barringer and Yardley 2007, A11.

56. Rabe, Roman, and Dobelis 2005, 9; and Rabe 2004, 34, 110, 133.

57. Betsill and Bulkeley 2004, 483, 488; and Bulkeley and Betsill 2003, 124-125.

58. Kelley 2006, A11.

59. Koehn 2006, 384-388. 
tal electricity package reported that "if we had characterized this as something to do with greenhouse gases, it would have hurt the bill's chances. So we didn't." ${ }^{60}$

\section{The Critical Importance of Framing for GHG-Emission Reductions}

Social-constructivist analysis rests on two basic tenets: ${ }^{61}$ that shared ideas rather than material influences are the primary determinants of collective action and that the interests of stakeholders primarily are shaped by learned values and perceptions. Applying these two tenets to the challenge of GHG-emissions limitation/reduction points to the importance of local-level value and policy "framing." Framing is intended to assign meaningful and potent interpretations of conditions and events. ${ }^{62}$ For environmental as well as other contested issues, framing "shapes the definitions of risk, the terms of participation, the range of policy options considered, and the nature of political debate." ${ }^{13}$ The core framing task of principal interest in this analysis is providing a powerfully resonating "rationale for engaging in ameliorative or corrective action." ${ }^{64}$ Because meaningful motivational frames "organize experience and guide action, whether individual or collective," 65 they play a critical part in activating human behavior that affects GHG emissions.

Subnational units of government are the governance structures closest to individual and many institutional end-use consumers. Their elected and appointed officials are positioned to perform community-sensitive and politically accepted framing roles. Choice of a subnational government focus for this article does not diminish the role of other frame actors. Certainly, the climaticchange discourse involves "competing authority claims and a plurality of voices" ${ }^{66}$ - particularly those of nongovernmental actors. ${ }^{67}$

Any subnational government framing strategy aimed at changing individual and collective behavior must "understand what motivates people to act." "68 For most people, values derived from direct life experience are more deeply held and predictive of consumptive behavior than are abstractly derived values. ${ }^{69}$ As long as the creeping physical signals of global warming are not perceived through direct personal experience, it will be difficult to alter prevailing cultural perspectives, risk assessments, and participation activity. ${ }^{70}$ However, there are outcomes that accompany anthropogenic GHG emissions (for instance, air pollution) that are directly and quickly observable. Given that the currently perceived personal threat of global warming typically is spatially and temporally re-

60. Rabe 2002, 15, 26.

61. This discussion is adapted from Wendt 1999, 1, 7, 193.

62. Snow and Benford 1988, 198.

63. Miller 2006, 380.

64. Snow and Benford 1988, 199, 211.

65. Snow, Rochford, Worden, and Benford 1986, 464.

66. Newell 2000, 167.

67. See Koehn 2006.

68. Bauer 2006a, 1.

69. Fazio and Zanna 1981, 195.

70. Jamieson 2006, 98. 
mote and that, at present, few citizens or government bodies permanently curtail consumption out of exclusive concern for its climatic impact, ${ }^{71}$ we also need to explore the promise for subnational government action in the PRC and the USA of issue bundling with directly experienced public concerns.

\section{Emerging Subnational Frame-Extension Opportunities}

As long as the associated community and personal threats and benefits are perceived to be relatively small, ${ }^{72}$ we can expect that few citizens or subnational governments in the United States and China will be willing to curtail practices that exacerbate global warming out of exclusive concern for their climatic impact. ${ }^{73}$ When it comes to tackling the daunting challenge of controlling consumption, in particular, climatic-change framing must be extended to encompass and activate powerful additional motivators. For the foreseeable future, therefore, the key to widespread emission-mitigating actions will be issue bundling in ways that link climatic stabilization to cherished place-based values ${ }^{74}$ and embed the local co-benefits of lower-carbon pathways in sustainabledevelopment narratives. ${ }^{75}$ The bundling, or frame-extension, process must resonate in compelling ways with local grievances and desires. ${ }^{76}$ Three categories of potential consumption and GHG-emission connections to perceived community, family, and personal concerns/benefits are likely to activate local action: environmental protection, health promotion, and economic security. In both China and the United States, frame-extension opportunities in each value area are "emerging" at the subnational government level in the sense that one encounters recent initiatives of considerable, but unfulfilled, potential. ${ }^{77}$

\section{Local Environmental-Protection Co-Benefits}

One appealing co-benefit of GHG-emission reductions is linkage with local environmental concerns. Recent developments indicate that sizeable segments of the Mainland public are tiring of complacency and complicity on the part of subnational authorities in the face of rural and urban environmental degradation. A growing number of China's local governments have experienced a groundswell of public protest against the dire economic and health conse-

71. Bord, Fisher, and O'Connor 1998, 78, 81, 83-84.

72. It is possible that the widely reported devastation wrought by hurricanes Katrina and Rita will have a long-term impact on US perceptions of the direct personal threat of global warming. The principal framing challenge in this connection is value and belief "amplification" (see Snow, Rochford, Worden, and Benford 1986, 469-471).

73. Bord, Fisher, and $\mathrm{O}^{\prime}$ Connor $1998,81,83-84$.

74. See Bauer 2006b, 67-68.

75. Roberts and Parks 2006, 24.

76. Snow, Rochford, Worden, and Benford 1986, 472, 477. Because framing strategies are variable and complex, they demand political sensitivity and ingenuity on the part of local government authorities. For instance, a particular set of grievances or desires might be emphasized for different target audiences. Rabe, Roman, and Dobelis 2005, 50.

77. See, for instance, Betsill and Bulkeley 2004, 486-490. 
quences of severe and unmitigated pollution. According to official sources, China experienced 87,000 mass demonstrations or riots during $2005 .{ }^{78}$ Some of the Mainland's spontaneous public uprisings, including incidents in Dongyang, Xinchang, Huaxi, and Dongzhou, centered on environmental and health degradations. ${ }^{79}$ Occasionally, village chiefs and local party officials have supported rural protests. ${ }^{80}$ Has spreading social unrest over pollution and environmental degradation opened a new window for subnational framing of GHG-emission mitigation in China?

At the same time that US overseas military deployments dramatically accelerate GHG emissions, ${ }^{81}$ their massive costs ${ }^{82}$ consume financial resources that might have addressed pressing domestic sustainable-transportation and GHGmitigation needs. Furthermore, during the Bush Administration's term in office, the national Environmental Protection Agency (EPA) has not regulated carbon dioxide, methane, nitrous oxide, and hydrofluorocarbons as air pollutants. Although the Supreme Court ruled in 2007 that the EPA possessed the authority to regulate GHGs in a case filed by Massachusetts and eleven other states, ${ }^{83}$ Bush refused to instruct the Agency to take this action on the ground that "China will produce greenhouse gases that will offset anything we do in a brief period of time." ${ }^{\prime 84}$ While the national government ignores the linkage possibilities, US subnational governments are engaged in a number of innovative initiatives that simultaneously mitigate GHG emissions and reduce local pollution. For instance, the states of Massachusetts and New Hampshire have expressly included $\mathrm{CO}_{2}$ in their "multi-pollutant" clean-air strategies. ${ }^{85}$

Community environmental concerns are the focus of attention in the following co-benefits discussion. First, we explore linkages between emissions mitigation and reduced environmental degradation (especially air pollution). This analysis is followed by consideration of frame-extension strategies that involve diminished resource consumption and depletion.

Reduced Environmental Degradation: One powerful framing strategy links GHGemission reductions to improvements in air quality. Lay publics are particularly receptive to controlling emissions that negatively affect living and working spaces. Betsill and Bulkeley discovered that existing concerns about air quality frequently drew US local governments into the Cities for Climate Protection (CCP) program. ${ }^{86}$ Moreover, Vasi found that many "innovation champions" working for CCP member governments "explicitly associate activities against

\footnotetext{
78. Kahn 2006, A10.

79. Yardley 2005.

80. Willmott 2006, 15.

81. See Barnett 2003, 13

82. Bilmes 2005, A27.

83. Greenhouse 2007, A1, A14.

84. Barringer and Yardley 2007, A1.

85. Rabe 2002, 16; and Rabe 2004, 77.

86. Betsill and Bulkeley 2004, 480.
} 
global climate change with measures for improving local air quality . . ."87 In China, "the increasing availability of public information on pollution" and the related rise in demands for action ${ }^{88}$ enhances the attractiveness of this frameextension option among local authorities.

By promoting renewable-energy projects, subnational governments are able to link local interests and policy-making authority with respect to controlling air pollution to climatic-stabilization goals that only can be realized through world-wide efforts. ${ }^{89}$ Promising alternatives to fossil-fuel combustion in both China and the United States include the adoption of solar power, wind power, geothermal power, and fuel cells. ${ }^{90}$ Large wind turbines and small household models figure prominently in the zero-emissions design for Dongtan. Increased reliance on renewable energy sources in the PRC simultaneously would mitigate China's severe urban air pollution problems and reduce the harmful effects of transPacific pollutants on the western United States.

Policies enacted by the Texas legislature in the late 1990s have resulted in dramatic increases in reliance on wind power and an estimated annual reduction in $\mathrm{CO}_{2}$ emissions of 1.83 million tons. ${ }^{91}$ The New Jersey state government relies on renewable sources for 15 percent of its electricity purchases. ${ }^{92}$ By mid 2006, 22 state governments had implemented Renewable Portfolio Standards policies that mandate that renewable energy provide an increasing share of each state's electrical power, including 25 percent of New York's electricity, by 2013. ${ }^{93}$ At the municipal level, the city of Colorado Springs adopted an energy program requiring that 15 percent of the energy sold within its limits come from wind sources by $2017 .{ }^{94}$

In light of its substantial and rapidly increasing contribution to domestic and global $\mathrm{CO}_{2}$ emissions, "any serious GHG mitigation strategy must include the [US] transportation sector." ${ }^{\prime 95}$ Increasingly, states are encouraging mass transit and teleworking. ${ }^{96}$ The state of Washington and more than 70 local governments in nine of its counties have enacted measures that require large-scale employers to reduce employee commuting. ${ }^{97}$ Decreasing the need to travel also is a central component in many of the targeted emissions-reduction programs adopted by member governments in the Cities for Climate Protection program..$^{98}$

The state of California, the largest automobile market in the USA, has ini-

87. Vasi 2005, 78, 94.

88. Porter, Han, and Shidong 2003, 7, 24; and Yu, et al. 2005, 55-56.

89. Rabe, Roman, and Dobelis 2005, 32.

90. DePalma 2006; Jamison 2007.

91. Rabe 2002, 13, 15 .

92. Rabe 2002, 38.

93. Rabe 2006, iii, v-vi, 4-5, 20.

94. Johnson 2004, A13.

95. Greene and Schafer 2003, iii.

96. Rabe 2002, 26, 29.

97. Rabe 2002, 29.

98. Betsill and Bulkeley 2004, 487. 
tiated the most far-reaching action to reduce transportation emissions. If its ground-breaking initiative withstands auto-industry challenges in the courts and with the EPA, California's tough standards on tailpipe emissions of $\mathrm{CO}_{2}$ and other greenhouse gases will be adopted by northeastern and west-coast states that account for 30 percent of all vehicles on US roads..$^{99}$

In 1996, 8 out of every 1000 inhabitants owned a car in the China Mainland-versus 769 per 1000 in the USA. Transportation accounted for only 8 percent of China's total carbon emissions in 1998-versus 30 percent in the USA. ${ }^{100}$ However, government data indicate that some 17 million private vehicles (13 per 1000 persons) navigated Mainland roads by $2005^{101}$ and analysts expect that "under a business-as-usual scenario, China's transportation fuel consumption will reach current U.S. levels by 2030." 102

Substantial transportation-emission reductions are feasible in China via issue bundling with local environmental concerns. Most of the world's most polluted cities are in China, ${ }^{103}$ and vehicle emissions have replaced coal soot as the principal source of urban air pollution. ${ }^{104}$ In response, some urban local governments in China are in the forefront worldwide in terms of active pursuit of systems that incorporate fuel cells, electric drive, batteries, and hybrid combinations. ${ }^{105}$ These subnational pollution-control initiatives include fuel-cell buses, cars, and motor scooters along with a hydrogen-infrastructure system ${ }^{106}$ and application of "intelligent transportation system" (ITS) technologies. ${ }^{107}$ The Shanghai, Beijing, and Guangzhou municipalities have implemented automotive-emission-control policies that are "stricter than central policies." ${ }^{108}$ Successful implementation of municipal efforts to improve air quality in the transport sector simultaneously curtails China's GHG emissions.

Diminished Resource Consumption and Depletion: Energy-efficiency innovations cannot be counted on to limit or reduce emissions levels by themselves because, by lowering costs, enhanced efficiencies typically result in demand for additional materials and fossil-fuel-generated energy. Thus, attention also needs to be devoted to unsustainable consumption levels in the USA and to the stress on natural resources arising from China's projected population of 1.6 billionincluding an additional 126 million increasingly affluent households by 2015. ${ }^{109}$ Durable voluntary reductions in emissions-generating consumption rarely occur in the absence of issue bundling. Collective and increasingly net-

99. Broder 2007; and Barringer and Yardley 2007, A11.

100. Sperling and Salon 2002, 14, 4; and Qian, Finamore, and Clegg 2003, 36.

101. www.zhb.gov.cn/english/news_detail.php3?id?13015, accessed 4 December 2006.

102. He 2003, 13.

103. Murray and Cook 2004, 9.

104. Qian, Finamore, and Clegg 2003, 35

105. Sperling and Salon 2002, 17, 19; and Cody 2006, G2.

106. Qian, Finamore, and Clegg 2003, 38-40; and He 2003, 15.

107. Sperling and Salon 2002, 18.

108. Notar 2006, 92-95.

109. Diamond 2005, 376. 
worked efforts that link reduced consumption to other motivators abound. One powerful motivator among inhabitants of both countries is concern for the welfare of future generations. ${ }^{110}$

Concern for future generations demands that the "downstream" GHGemission consequences of production and consumption practices be taken into account. The volume of waste that results from expanded production and consumption inevitably requires additional energy expenditures and generates increased GHG emissions at the disposal stage. For instance, massive exports of discarded plastic and toxic e-waste from the United States to China require Mainland governments at all levels to assume responsibility for disposal processes that exacerbate local pollution, GHG emissions, and long-term health risks. ${ }^{111}$ The unregulated dumping of obsolete US computers and monitors containing toxic materials often overwhelms complicit Mainland local governments that already face daunting domestic waste-disposal challenges. ${ }^{112}$ In 2002, the Basel Action Network (BAN), the Silicon Valley Toxics Coalition, and Green Peace China reported on the debilitating consequences of e-waste dumping in Guiyu. ${ }^{113}$ Since the US Government refuses to ratify the Basel Convention and continues to envision exportation as a central part of the country's e-waste disposal strategy, ${ }^{114}$ subnational governments in China and the United States need to engage one another directly regarding healthier ways to handle the generation and disposal of e-waste. ${ }^{115}$ Sustainable waste-management reductions in downstream emissions also require durable changes in "upstream" consumption and mandatory take-back designs.

\section{Health-Promotion Co-Benefits}

An important emission-mitigation framing strategy that is emerging at the subnational level incorporates health and stress considerations. Many actions that reduce GHG emissions over the long-term also immediately lower personal stress and dramatically diminish direct and indirect threats to personal and family health. Decreased exposure to the particulate matter that is associated with the operation of coal-fire plants and petrol-driven vehicles would avoid an estimated 33,000 deaths per year in the USA by 2020, save far more lives in China, and provide substantial public-health benefits for inhabitants of both countries. ${ }^{116}$ Since the negative health consequences associated with fossil-fuel combustion processes are directly and quickly discernable, connecting GHG

110. See Koehn 2006, 398.

111. Clapp 2002, 165.

112. Flynn 2005, C5; and Murray and Cook 2004, 108-113.

113. Puckett et al. 2002, 15-23.

114. Puckett et al. 2002, 9, 11.

115. I am grateful to an anonymous reviewer for suggesting this point. These discussions, as well as other cooperative emission-mitigating endeavors involving municipal governments in the PRC and USA, could take place through sister-city network linkages-among other avenues. See Cheung and Tang 2001, 99, 108.

116. Koehn 2006, 393. 
emissions, air pollution, and health offers subnational governments a potent framing strategy.

The power of a framing strategy that links emissions mitigation with public health is illustrated by the case of Benxi, a mid-sized industrial city in Liaoning Province. ${ }^{117}$ Subnational officials, led by the director of the city's Environmental Protection Bureau (EPB), the mayor and deputy mayor, and Liaoning Province's EPB director, successfully transformed Benxi from the infamous city that could not be seen on satellite images due to the heavy smog that engulfed it into a model city for source-point pollution control and prevention. Studies showed that mortality from lung cancer had increased 2.3 times in Benxi from 1971 to 1982 and continued to rise in industrial but not in less-polluted areas after 1986. City officials persuasively "showcased" the link between air pollution and lung cancer along with other respiratory diseases in extensive public-education campaigns, a "green-schools" initiative, and funding appeals to higher authorities and international donors. ${ }^{118}$

In the United States, the state of California's leadership in capping allowable $\mathrm{CO}_{2}$ emissions has been framed, in part, as a local public-healthpromoting initiative that especially benefits smog-afflicted communities. ${ }^{119}$ In 2006, the Democratic controlled legislature and Republican Governor Arnold Schwarzenegger reached an attention-generating agreement on a bill that imposes a 25 percent reduction in the state's $\mathrm{CO}_{2}$ emissions by $2020 .{ }^{120}$

Transportation choices merit special attention in connection with bundling health, pollution control, and emission reductions. China's vehicle emissions are associated with "brain damage, respiratory problems and infections, lung cancer, [and] emphysema." ${ }^{121}$ A joint UNDP-WHO study found air pollution responsible for an estimated 500,000 unnecessary deaths per year in 28 Mainland urban centers. ${ }^{122}$ China's population also has experienced a dramatic rise in obesity, diabetes, and abnormal blood lipid levels linked, in part, to recent declines in cycling and walking in favor of automobiles. ${ }^{123}$ Appeals to people's health concerns constitute particularly promising avenues for reducing vehicle emissions because they convincingly link visible air pollution to compelling personal motivations for diminished motor-vehicle use.

In order to address air-pollution concerns, prominent subnational governments in China have demonstrated serious interest in leapfrogging to buses, automobiles, and scooters that incorporate fuel cells, electric drive, compressed natural gas, batteries, and biomass fuels. ${ }^{124}$ The Shanghai Municipality has pursued alternatives to car ownership and usage. In its model approach to GHG-

117. The following discussion of Benxi is based on Yu, et al. 2005.

118. UNDP partnered with the municipal government of Benxi on a project designed to strengthen "municipal capacity for clean technology promotion." Yu, et al. 2005, 42, 84.

119. Rabe, Roman, and Dobelis 2005, 9, 18.

120. Barringer 2006a.

121. Paterson 2000, 259; and Sperling and Salon 2002, iv.

122. Porter, Han, and Shidong 2003, 40, 22n.

123. See Koehn forthcoming.

124. Koehn 2006, 395. 
emissions reductions, Shanghai has explicitly integrated air quality and healthimpact considerations. ${ }^{125}$

In the United States, increases in child obesity can be attributed, in part, to the precipitous decline in the percentage of the school-age population who ride bicycles to school. At the local level, the provision of cyclist- and pedestrianfriendly routes and providing incentives for curtailing short car trips-particularly during peak traffic hours-can bring about a substantial reduction in US fossil-fuel emissions ${ }^{126}$ and keep obesity and type-2 diabetes in check. ${ }^{127}$ It is noteworthy, therefore, that municipal policy makers in health-conscious communities such as Corvallis and Portland, Oregon, Palo Alto, California, Missoula, Montana, and Boulder, Colorado, have taken the lead in promoting and facilitating the development of bicycle-friendly communities. ${ }^{128}$

\section{Economic Co-Benefits}

The third subnational frame-extension strategy that has emerged in China and the United States links emissions limitation and reduction to economic cobenefits. The bundled benefits include economic-development, employment opportunities, and cost savings.

China's post-WTO-accession reforms empower local governments to authorize foreign investments in green technologies such as zero-emission wind power. Green technology potentially constitutes "the most important industry of the $21^{\text {st }}$ century" and China is poised to be a leading green-technology exporter within the next decade. ${ }^{129}$ Among the R\&D possibilities are hydrogen storage and refueling stations and zero-pollution zinc-air-battery-powered bicycles. ${ }^{130}$ Local governments provide, or help secure, the requisite venture capital and technology-transfer training for a variety of small- and modest-scale urban and rural projects that mitigate GHG emissions and simultaneously are employment-generating. Provincial governments, for instance, have subsidized the local establishment of labor-intensive Suntech factories that manufacture silicon photovoltaic cells. ${ }^{131}$ At subnational levels, China's public entrepreneurs already have successfully promoted efforts to produce, disseminate, and maintain small-scale wind turbines that supply cost-effective energy. ${ }^{132}$ Further development of China's localized wind industry promises to result in considerable employment generation. ${ }^{133}$

Increasingly, political leaders at the state and city level in the USA perceive

125. Chiu, Green, and Sibold 2003, 42-44, 47; and Koehn 2004, 388.

126. See Andrews 2006.

127. Brody 2006. An estimated 97 million US Americans, nearly one-third of the total population, are obese. Darlin 2006, B6.

128. Devlin 2003.

129. Friedman 2005a.

130. Tao 2003, 50; and Greene and Schafer 2003, iv.

131. Friedman 2006.

132. Lew $2000,272,283-284$.

133. Raufer and Wang 2003, 46. 
and promote GHG-emissions-mitigation strategies as supportive of long-term economic interests. Across the US west, for instance, new coalitions of conservation, agricultural, tourist-industry, and even utility interests are supporting renewable-energy and GHG-reduction initiatives. ${ }^{134}$ Other subnational proponents of climate change mitigation emphasize the cost-savings that accompany innovative energy-efficient operations along with the economic-development opportunities associated with renewable-energy ventures. ${ }^{135}$ Officials in California, for instance, have "consistently linked concern about climate protection with economic development opportunities." ${ }^{136}$ Policy makers in Texas have successfully cultivated support for wind farms by emphasizing "entrepreneurial opportunities for renewable energy developers. . . ."137 Most US local governments constantly are under pressure to cut costs. Vasi found that linking emission reductions to "saving money" has been a particularly effective framing strategy among Cities for Climate Protection members. ${ }^{138}$

Recent extreme weather events in both China and the United States are likely to have encouraged additional local government leaders to consider framing climatic-stabilization measures in cost-savings terms. More than half of the US population lives in areas adjacent to or near a coast ${ }^{139}$ that are increasingly vulnerable to rising sea levels and storm-induced flooding. Hurricane Katrina and its aftermath obliterated the tax base for municipal governments in southern Louisiana at the same time that the damage it inflicted imposed catastrophic social and economic costs. Faced with unprecedented financial burdens, officials in New Orleans and other Gulf Coast municipalities had no choice but to institute massive employee layoffs and service reductions. ${ }^{140}$ In August 2006, super-typhoon Saomai, the strongest to hit China in 50 years, devastated homes and infrastructure in the southeastern province of Zhejiang. ${ }^{141}$ The impact of both storms has increased public awareness that adaptation to climatic change will be a costly proposition. As Stephen Schneider has pointed out, GHGemission reductions are cost-effective in the long run. ${ }^{142}$

\section{Conclusion}

Climate change politics have moved beyond scientific studies, international agreements, and national government actors. In the absence of national politi-

134. Brownstein 2007, A8; also see Zezima 2007. In an April 2007 New York Times/CBS News poll, 75 percent of the US public expressed willingness to "pay more for electricity if it were generated by renewable energy sources like solar or wind" in order to reduce global warming. Broder and Connelly 2007.

135. Rabe 2006, 6-7; and Betsill and Bulkeley 2004, 482.

136. Rabe, Roman, and Dobelis 2005, 9, 38.

137. Rabe, Roman, and Dobelis 2005, 10.

138. Vasi 2005, 76-77, 81, 94 .

139. Rabe, Roman, and Dobelis 2005, 25.

140. Medina and Hauser 2005, A27.

141. New York Times, 11 August 2006, A4.

142. Glenn 2006, A18. In 1997, the World Bank estimated the health costs associated with air- 
cal will and the commitment of adequate financial resources at the center, the local and transnational initiatives of subnational governments and nonstate actors operating "underneath Kyoto" have been inspiring and will continue to have an important mitigating impact for the foreseeable future. In a development that illustrates the multilayered and transnationally connected nature of contemporary global governance, four US city governments and two environmental NGOs have secured standing to sue two national government agencies (the Overseas Private Investment Corporation and the Export-Import Bank) in an effort to halt US-supplied loans and insurance coverage for overseas power plants that emit greenhouse gases. The city government/NGO coalition argued that such overseas projects are subject to National Environmental Policy Act regulations since they contribute to degradation of the US environment. ${ }^{143}$

At regional, state/provincial, and local levels in both China and the United States, there is growing appreciation for the power of framing proactive subnational efforts to address global warming in connection with local cobenefits that extend "beyond climate." 144 In a political context characterized by governmental fragmentation, and inaction by those currently in power at the center of the nation-state, increasingly independent subnational governments are emboldened to participate in emissions-limitation and emissions-reduction activity through cooperation with NGOs, business firms, and transnational actors that focus on air-quality, health-promotion, cost-savings, economicdevelopment and employment, and renewable-energy opportunities. ${ }^{145}$ Working in concert with transnationally competent overseas Chinese is likely to be especially fruitful for China's local governments. ${ }^{146}$

For the most part, China's cities and provinces have not yet adopted policy strategies that address GHG emissions directly. ${ }^{147}$ Nevertheless, the subnational government initiatives that are starting to affect GHG emissions in China and in every region of the United States carry widespread public appeal because the cobenefits of mitigation are highly valued at the grass-roots level. In an impressive group of US states and cities, and increasingly at the local level in China, public concerns about air pollution, consumption and waste management, traffic congestion, health threats, the ability to attract tourists, and/or diminishing resources are legitimizing policy developments that carry the co-benefit of controlling GHG emissions. Collectively, expanding and emerging subnational government efforts to promote renewable energy, reduce urban air pollution,

pollution-generated respiratory diseases in China's cities at 13 percent of GDP. Cited in Porter, Han, and Shidong 2003, 22.

143. Kravets 2005, A6.

144. Rabe, Roman, and Dobelis 2005, 3-4, 9-10.

145. For Mayor's Rocky Anderson's framing of Salt Lake City's successful efforts to "combat global warming" in these terms, see Anderson 2006.

146. See Koehn 2004; and Koehn 2006.

147. However, some Mainland local governments have acted as "trendsetters' . . . with respect to the development of influential legal measures . . . for protection of the environment." Ferris and Zhang 2005, 75, 81-82. 
and embrace emission-reduction targets "constitute a diverse set of policy innovations rich with lessons" for climatic stabilization. ${ }^{148}$

In an environment of multilayered politics, the strengths of decentralized governmental systems include enhanced competition, innovation, experimentation, and adaptation to local conditions. ${ }^{149}$ Thus, it is not surprising that local policy framing enables subnational levels of government to become "more capable and innovative than their central-level counterparts"150 in the climaticchange arena. Eventually, local emission-mitigation initiatives will need to be enhanced by increasingly proactive national governments. Although climate protection cannot be addressed entirely at the subnational level, in China and the United States today the principal issue-bundling impetus for emissionsmitigation-policy and consumptive-behavior change is bubbling and spreading from the bottom up.

Maximizing the capacity of subnational governments to deal with the daunting climatic-change challenges raised by population and consumption trajectories in both countries requires that additional US states and cities, and Mainland provinces, municipalities, and townships adopt politically palatable framing strategies. In order to take full advantage of arising opportunities to influence individual and collective behavior, local authorities must be trusted and transparent and their framings must be "credible and persuasive."151 A cobenefits framing strategy that links individual and specific community concerns for morbidity, mortality, stress reduction, and healthy human development for all with GHG-emission limitation/reduction and renewable-energy development is especially likely to resonate powerfully and non-competitively at the subnational level throughout China and the United States. ${ }^{152}$

\section{References}

Anderson, Rocky. 2006. Warming Trend Can Be Reversed with Current Technology, Commitment. Missoulian, 21 July, A8.

Andrews, Edmund L., and Felicity Barringer. 2007. Bush Seeks Vast, Mandatory Increase in Alternative Fuels and Greater Vehicle Efficiency. New York Times, 24 January, A14.

Andrews, Mea. 2006. Pedal to Save the Planet, Speaker Says. Missoulian, 28 April, A1, A10. Barnett, Jon. 2003. Security and Climate Change. Global Environmental Change 13 (1): 7 17.

148. Rabe 2002, ii; also see Woodard 2006, 24.

149. Orban, Chen, and Koehn 2003, 251-252.

150. Rabe 2002, 3.

151. Miller 2006, 386, 381. Building public trust in local government officials' commitment to addressing pollution remains an important challenge in China. See Lee 2005, 52; and Yu, et al. 2005, 53, 93.

152. In particular, the joint UNDP-WHO finding that nearly half a million unnecessary Chinese deaths can be attributed annually to air pollution needs to figure more prominently in local framings of GHG-emission-limitation initiatives. See Porter, Han, and Shidong 2003, 45, 40. 
Barringer, Felicity. 2006a. Officials Reach California Deal to Cut Emissions. New York Times, 31 August, A1, A20.

2006b. White House Presents Plans to Cut Emissions. New York Times, 21 September, A27.

Barringer, Felicity, and William Yardley. 2007. Bush Splits on Greenhouse Gases with Congress and State Officials. New York Times, 4 April, A1, A11.

Bauer, Joanne. 2006a. Introduction. In Forging Environmentalism: Justice, Livelihood, and Contested Environments, edited by Joanne Bauer, 1-21. Armonk, NY: M.E. Sharpe. . 2006b. Whose Environment? China Rights Forum 1: 64-70.

Betsill, Michele M., and Harriet Bulkeley. 2004. Transnational Networks and Global Environmental Governance: The Cities for Climate Protection Program. International Studies Quarterly 48: 471-493.

Bilmes, Linda. 2005. The Trillion Dollar War. New York Times, 20 August, A27.

Bord, Richard J., Ann Fisher, and Robert E. O'Connor. 1998. Public Perceptions of Global Warming: United States and International Perspectives. Climate Research 11: 75-84.

Bradsher, Keith. 2006. China to Pass U.S. in 2009 in Emissions. New York Times, 7 November, $\mathrm{C} 1, \mathrm{C} 4$.

Broder, John M. 2007. California Wants Strict Auto Emission Rules. New York Times, 23 May, A16.

Broder, John M., and Marjorie Connelly. 2007. Public Says Warming Is a Problem, but Remains Split on Responses. New York Times, 27 April, A23.

Brody, Jane E. 2006. Time to Get Out, for the Body and the Mind. New York Times, 14 February, D7.

Brownstein, Ronald. 2007. The Greening of the West. Missoulian, 11 April, A8.

Bulkeley, Harriet, and Michele M. Betsill. 2003. Cities and Climate Change: Urban Sustainability and Global Environmental Governance. London: Routledge.

Bush, George W. 2001. Global Climate Change: Making Commitments We Can Keep and Keeping Commitments We Can Make. Vital Speeches of the Day 68 (18): 546-548.

Chen, Sulan, and Juha I. Uitto. 2003. Governing Marine and Coastal Environment in China: Building Local Government Capacity through International Cooperation. China Environment Series 6: 67-80.

Chen, Xiaoyuan. 1998. Strengthening Grassroots Cooperation: Exchanges of Information, Approaches, and Personnel among Chinese and American Municipalities. Paper presented at the International Symposium on The Outlook for China-USA Relations Following the 1997-1998 Summits: Chinese and U.S. Perspectives, 28-29 May, Hong Kong.

Cheung, Peter T. Y., and James T. H. Tang. 2001. The External Relations of China's Provinces. In The Making of Chinese Foreign and Security Policy in the Era of Reform, 19782000, edited by David M. Lampton, 90-120. Stanford, CA: Stanford University Press.

Chiu, Kong, Collin Green, and Katherine Sibold. 2003. Air Quality and Greenhouse Gas Co-benefits of Integrated Strategies in China. Sinosphere Journal 6 (1) March: 4047.

Clapp, Jennifer. 2002. The Distancing of Waste: Overconsumption in a Global Economy. In Confronting Consumption, edited by Thomas Princen, Michael Maniates, and Ken Conca, 155-176. Cambridge, MA: MIT Press.

Cody, Edward. 2006. Shifting Priorities. Missoulian, 31 December, G1-2.

Cohen, Betsy. 2007. UM Joins Global Warming Coalition. Missoulian, 26 March, A1, A9. 
Darlin, Damon. 2006. More Pounds, Fewer Dollars: Being Overweight Can Limit Wealth as Well as Health. New York Times, 2 December, B1, B6.

DePalma, Anthony. 2006. Upstate New York Farms Begin Raising New Crop: Electricity from Windmills. New York Times, 13 March, A21.

Devlin, Vince. 2003. National Organization Names Missoula a Bicycle-friendly Community. Missoulian, 20 May, B1.

Diamond, Jared. 2005. Collapse: How Societies Choose to Fail or Succeed. New York: Viking.

Economy, Elizabeth C. 2004. The River Runs Black: The Environmental Challenge to China's Future. Ithaca, NY: Cornell University Press.

2005. Environmental Enforcement in China. In China's Environment and the Challenge of Sustainable Development, edited by Kristen A. Day, 102-120. Armonk, NY: M.E. Sharpe.

Fazio, Russell H., and Mark P. Zanna. 1981. Direct Experience and Attitude-behavior Consistency. Advances in Experimental Social Psychology 14: 161-202.

Ferris, Richard J., and Hongjun Zhang. 2005. Environmental Law in the People's Republic of China. In China's Environment and the Challenge of Sustainable Development, edited by Kristen A. Day, 66-101. Armonk, NY: M.E. Sharpe.

Flynn, Laurie J. 2005. Poor Nations are Littered with Old PC's, Report Says. New York Times, 24 October, C5.

Foster, Kenneth W. 2005. Chinese Public Policy Innovation and the Diffusion of Innovations: An Initial Exploration. Chinese Public Administration Review 3 (1/2) March/ June: $1-17$.

Friedman, Thomas L. 2005a. China's Little Green Book. New York Times, 2 November, A31.

2005b. Living Hand to Mouth. New York Times, 26 October, A27. 2006. China's Sunshine Boys. New York Times, 6 December, A27.

Gardiner, Stephen M. 2004. Ethics and Global Climate Change. Ethics 114 (April): 555600.

Gettleman, Jeffrey. 2006. Annan Faults 'Frightening Lack of Leadership' for Global Warming. New York Times, 16 November, A16.

Glenn, David. 2006. A Climate for Not Much Change. Chronicle of Higher Education, 31 March, A16-A18.

Graham-Harrison, Emma, and Gerard Wynn. 2007. China Seen Topping U.S. Carbon Emissions in 2007. Reuters, 23 March.

Greene, David L., and Andreas Schafer. 2003. Reducing Greenhouse Gas Emissions from U.S. Transportation. Arlington, VA: Pew Center on Global Climate Change.

Greenhouse, Linda. 2007. Justices Say E.P.A. Has Power to Act on Harmful Gases. New York Times, 3 April, A1, A14.

Hale, David. 2004. China's Growing Appetites. National Interest 76 (Summer): 137-147.

He, Dongquan. 2003. Introduction to the China Sustainable Energy Program's Transportation Program. Sinosphere Journal 6 (1) March: 13-17.

Jamieson, Dale. 2006. An American Paradox. Climatic Change 77: 97-102.

Jamison, Michael. 2007. Power Plan Sets Lofty Wind Goal. Missoulian, 23 March, A1, A4.

Janofsky, Michael. 2004. U.S. and 13 Other States Agree to Push to Gather Methane Gas. New York Times, 17 November, A5.

Johnson, Kirk. 2004. Coloradans Vote to Embrace Alternative Sources of Energy. New York Times, 14 November, A13. 
Kahn, Joseph. 2006. Pace and Scope of Protest in China Accelerated in '05. New York Times, 20 January, A10.

Kelley, Katie. 2006. City Approves 'Carbon Tax' In Effort [to] Reduce Gas Emissions. New York Times, 18 November, A11.

Koehn, Peter H. 2004. Sustainable-development Frontiers and Divides: Transnational Actors and U.S./China Greenhouse-gas Emissions. International Journal of Sustainable Development and World Ecology 11 (4): 380-396.

2006. Fitting a Vital Linkage Piece into the Multidimensional Emissionsreduction Puzzle: Nongovernmental Pathways to Consumption Changes in the PRC and the USA. Climatic Change 77: 377-413.

. 2007. Global Climatic Stabilization: Challenges for Public Administration in China and the United States. In Handbook of Globalization, Governance, and Public Administration, edited by Ali Farazmand and Jack Pinkowski, 1089-1135. Boca Raton, FL: CRC Press.

. Forthcoming. Back to the Future: Bicycles, Human Health, and Greenhouse Gas Emissions in China. China Environment Series 9.

Kravets, David. 2005. Judge: Global Warming Lawsuit Can Go Forward. Missoulian, 25 August, A6.

Kugler, Sara. 2007. World Mayors Say Cities Have the Ability and Responsibility to Fight Climate Change. Missoulian, 16 May, A7.

Kull, Steven. 2005. Americans on Climate Change: [5 July] 2005. PIPA/Knowledge Networks Poll. Available at www.pipa.org

Lee, Yok-shiu F. 2005. Public Environmental Consciousness in China: Early Empirical Evidence. In China's Environment and the Challenge of Sustainable Development, edited by Kristen A. Day, 35-65. Armonk, NY: M.E. Sharpe.

Lew, Debra J. 2000. Alternatives to Coal and Candles: Wind Power in China. Energy Policy 28, 271-286.

Ma Kai. 2007. China Is Shouldering Its Climate Change Burden. Financial Times, 3 June.

Medina, Jennifer, and Christine Hauser. 2005. Local Governments Face Bankruptcy, Layoffs or Both. New York Times, 4 October, A27.

Miller, Clark A. 2006. Framing Shared Values: Reason and Trust in Environmental Governance. In Forging Environmentalism: Justice, Livelihood, and Contested Environments, edited by Joanne Bauer, 377-394. Armonk, NY: M.E. Sharpe.

Murray, Geoffrey, and Ian G. Cook. 2004. The Greening of China. Beijing: China Intercontinental Press.

Nadler, Arnold. 2004. Carbon Sequestration: Can it Help Beat Back Global Climate Change? Public Power 62 (May-June): 16-23.

Newell, Peter. 2000. Climate for Change: Non-state Actors and the Global Politics of the Greenhouse. Cambridge: Cambridge University Press.

Niederberger, Anne A, Conrad U. Brunner, and Zhou Dadi. 2006. Energy Efficiency in China: Impetus for a Global Climate Policy Breakthrough? China Environment Series $8,85-86$.

Notar, Isabella. 2006. China's Cities Seize the Initiative: Strengthening Auto Emissions Control on the Streets. China Environment Series 8, 92-97.

Orban, Edmond, Xiaoyuan Chen, and Peter H. Koehn. 2003. Great-Power Decentralization and the Management of Global/Local Economic Policy and Relations: Lessons in Fluidity from the People's Republic of China. International Review of Administrative Sciences 69 (2) June: 235-258. 
Paterson, Matthew. 2000. Car Culture and Global Environmental Politics. Review of International Studies 26: 253-270.

People's Republic of China [PRC], Central People's Government. 2007. Full Text of PRC Climate Change Program. Beijing: CPG. Available at www.english.gov.cn.

People's Republic of China [PRC], State Council, Information Office. 2006. Environmental Protection in China (1996-2005). Available at www.zhb.gov.cn/english/news_ detail.php3?id?12841.

Perlez, Jane. 2006. Forests in Southeast Asia Fall to Prosperity's Ax. New York Times, 29 April, A1, A7.

Porter, Gareth, Shi Han, and Zhao Shidong. 2003. Energy and Environment Outcome Evaluation, 21 May. Beijing: UNDP China.

Puckett, Jim, et al. 2002. Exporting Harm: The High-tech Trashing of Asia. Available at www.crra.com/ewaste/ttrash2/ttrash2, accessed 4 December 2006.

Qian, Jingjing, Barbara Finamore, and Tina Clegg. 2003. Fuel Cell Vehicle Development in China. Sinosphere Journal 6 (1) March: 34-40.

Rabe, Barry G. 2002. Greenhouse and Statehouse: The Evolving State Government Role in Climate Change. Arlington, VA: Pew Center on Global Climate Change. 2004. Statehouse and Greenhouse: The Emerging Politics of American Climate Change Policy. Washington, D.C.: Brookings Institution Press. 2006. Race to the Top: The Expanding Role of U.S. State Renewable Portfolio Standards. Arlington, VA: Pew Center on Global Climate Change.

Rabe, Barry G., Mikael Roman, and Arthur N. Dobelis. 2005. State Competition as a Source Driving Climate Change Mitigation. New York University Environmental Law Journal 14: 1-53.

Raufer, Roger, and Shujuan Wang. 2003. Navigating the Policy Path for Support of Wind Power in China. China Environment Series 3: 37-49.

Roberts, J. Timmons, and Bradley C. Parks. 2006. A Climate of Injustice: Global Inequality, North-South Politics, and Climate Policy. Cambridge, MA: MIT Press.

Sassen, Saskia. 2004. The Repositioning of Citizenship. In People Out of Place: Globalization, Human Rights, and the Citizenship Gap, edited by Alison Brysk and Gershon Shafir, 191-208. London: Routledge.

Snow, David A., and Robert D. Benford. 1988. Ideology, Frame Resonance, and Participant Mobilization. In From Structure to Action: Comparing Social Movement Research Across Cultures, edited by Bert Klandermans, Hanspeter Kriesi, and Sidney Tarrow, 197-217. Greenwich, CN: JAI Press.

Snow, David A., E. Burke Rochford Jr., Steven K. Worden, and Robert D. Benford. 1986. Frame Alignment Processes, Micromobilization, and Movement Participation. American Sociological Review 51 (August): 464-481.

Sperling, Daniel, and Deborah Salon. 2002. Transportation in Developing Countries: An Overview of Greenhouse Gas Reduction Strategies. Arlington, VA: Pew Center on Global Climate Change.

Steinberg, Paul F. 2001. Environmental Leadership in Developing Countries: Transnational Relations and Biodiversity Policy in Costa Rica and Bolivia. Cambridge, MA: MIT Press.

Steinhauer, Jennifer. 2006. Clinton Foundation to Work to Reduce Greenhouse Gases. New York Times, 2 August, A16.

Sunstein, Cass R. 2006. Costly Decisions: If We Can Fund the War in Iraq, Why Not the Kyoto Protocol? Missoulian, 11 May, B4.

Tan, Zuoren. 2006. Our Land is Under Seige. China Rights Forum 1: 30-35. 
Tao, Nuyi (compiler). 2003. Environmental Briefing. Sinosphere Journal 6 (1) March: 5052.

Turner, Jennifer L (ed). 2002. Inventory of Environmental and Energy Projects in China. China Environment Series 5: 137-227.

Vance, Eik. 2007. Presidents Sign Commitment to Limit Emissions on Campuses. Chronicle of Higher Education, 23 February, A25-A26.

Vasi, Ion B. 2005. The Adoption and Implementation of Local Governmental Actions against Global Climate Change. Unpublished dissertation, Cornell University.

Wendt, Alexander. 1999. Social Theory of International Politics. Cambridge, UK: Cambridge University Press.

Willmott, Elizabeth. 2006. Common Cause: China's State-Society Response to Environmental Crisis. China Rights Forum 1: 15-21.

Woodard, Colin. 2006. The Global Warming Debate Reaches a Turning Point in the U.S. Trust 9 (1): 18-25.

Yardley, Jim. 2005. Riot in Rural China as Police Try to Halt Pollution Protest. New York Times, 14 April, A3.

Yu, Liu, Pan Wei, Shen Mingming, Song Guojun, Vivian Bertrand, Mary Child, and Judith Shapiro. 2005. The Politics and Ethics of Going Green in China: Air Pollution Control in Benxi City and Wetland Preservation in the Sanjiang Plain. In China's Environment and the Challenge of Sustainable Development, edited by Kristen A. Day, 31-101. Armonk, NY: M.E. Sharpe.

Zezima, Katie. 2007. In New Hampshire, Towns Put Climate on the Agenda. New York Times, 19 March, A8.

Zusman, Eric, and Jennifer Turner, 2005. Beyond the Bureaucracy: Changing China's Policymaking Environment. In China's Environment and the Challenge of Sustainable Development, edited by Kristen A. Day, 121-149. Armonk, NY: ME Sharpe. 